\title{
An Analysis of Discrepancy between the Lesson Plan and the Implementation of Curriculum 2013 in Teaching and Learning Process in SD Negeri 4 Kaliuntu
}

\author{
I Nyoman Laba Jayanta ${ }^{1,}{ }^{*}$, Kadek Dewi Suryantari ${ }^{2}$, Made Sumantri ${ }^{3}$ \\ 1 Departement of Primary School Teacher Education. Universitas Pendidikan Ganesha, Indonesia \\ ${ }^{2}$ Departement of Primary School Teacher Education. Universitas Pendidikan Ganesha, Indonesia \\ ${ }^{3}$ Departement of Primary School Teacher Education. Universitas Pendidikan Ganesha, Indonesia
}

\section{Abstract}

This research aimed to determine how large the discrepancy between the ideal condition and the implementation of 2013 curriculum in teaching and learning process in SD Negeri 4 Kaliuntu reviewed from the lesson plan and teaching learning process. This research was evaluative research which apply discrepancy model. Measurement of the program effectiveness was done by comparing the ideal conditions, based on Permendikbud No. 103 of 2014, with the real conditions on the implementation of 2013 Curriculum at SD Negeri 4 Kaliuntu. Lesson plan data, was measured by the study documentation methode. Meanwhile, the teaching and learning process data was measured by observation methode. Subject of this research consisted of 6 teachers of SD Negeri 4 Kaliuntu. The data scores was form for all variables were analyzed by using the Wilcoxon's signed rank test. The sign difference and score difference were calculated with a predetermined standard. The result of the analysis indicate that the large of discrepancy between ideal conditions (based on Permendikbud No. 103 of 2014) and the implementation of 2013 Curriculum in SD Negeri 4 Kaliuntu in terms of lesson plan is $12,17 \%$. The discrepancy lies on indicators of learning activities, assessment of learning result, media and learning resources. Reviewed from the teaching learning process, the discrepancy occurs at $19.17 \%$. The discrepancy occurs in the indicator of giving apperception, convey of evaluation techniques that will be used by teachers, students are directed reflection of the activities that have been implemented, and the provision of follow-up by giving remedial, enrichment, or giving assignments.
\end{abstract}

\section{Keywords:}

Discrepancy,

Lesson plan,

Teaching and learning

process,

Permendikbud no. 103/

2014

\section{Introduction}

Education has very significant role in creating the human beingswhich could determine the quality of a nation. The success of an education is absolutely supported by the related components, such as curriculum, teachers, students and facilities. Curriculum is one of the important components in implementing the education. The educational process in teaching and learning process or in the classroom can run well, conducive and interactive if curriculum can be the main support in teaching and learning process (Kamil, 2014). Curriculum can be said as the heart of education because the good and bad side of its result are based on the curriculum. Due to the significant role of the curriculum, in a period of time, curriculum is evaluated and adjusted with the development of times. During the history of education in Indonesia, the government has updated the curriculum for several times (Pertiwi, 2015). In 1994, the curriculum was curriculum 1994. However, because of the development demand, in this case the students' condition and needs in the present and future, curriculum 1994 was changed into competency based curriculum (KBK) which was launched to the society in 2004. After implementing KBK, it was updated again into a new curriculum in 2006 named units of education curriculum (KTSP). Nevertheless, because of the developmental era which was increasing, KTSP was changed into better curriculum named Curriculum 2013 in the academic year 2013/2014. 
The development of Curriculum 2013 is conducted because there is an internal and external challenge (Kemendikbud, 2013a). The internal challenge is related to the educational demand which concerns on the eight standards of the national education and Indonesian citizen developmental factor. The external challenge is related to the future challenge, the competency needed in the future, the people's perspective, the development of knowledge and pedagogic, and also the various negative phenomena. Permendikbud No 104 of 2014 stated that the student's achievement which is assessed by the teacher is the process of collecting the information or proofs of the learning performance of the students in the spiritual and social competency, knowledge competency, and skill competency which are conducted chronologically and systematically during and after the learning process. The authentic assessment is the form of assessment that expects the students to perform good attitude, knowledge and skill that have been achieved from the learning process while doing the assignment in the real context. The previous curriculum more concerns on the cognitive domain but Curriculum 2013 tends to balance it with psychomotor and affective domain (Pantiwati, 2013). The assessment of Curriculum 2013 must be able to balance the affective, cognitive and psychomotor assessment.

Curriculum 2013 is the advanced step of developing the competency based curriculum which has been established in 2004 and KTSP which has been introduced in 2006 that integrates the attitude, knowledge and skill. The learning process is designed in the form of student centered active learning, that does not focused on the teacher like what has been known as teacher centered learning. Besides, the contextual learning means teacher does not only use text book but also able to relate the teaching material contextually. The implementation of Curriculum 2013 is based on scientific approach (Kuriniasih dan Sani, 2014). The plan of Curriculum 2013 is centralistic, in which the state and local government control the quality of the curriculum implementation in a unit of education. The government prepares all components of the curriculum including the text book and guidance of writing syllabus. In line with the implementation of Curriculum 2013, the education in Indonesia is expected to be able to reach the standard. The government, in this case is the Ministry of Education and Culture, has established various regulations which are called as Peraturan Menteri Pendidikan dan Kebudayaan (Permendikbud). The regulation that has just published by the government which explains about the implementation of Curriculum 2013 including lesson plan and its learning process is Permendikbud No 103 of 2014 which is about elementary and high school education. Generally, according to Permendikbud No 103 of 2014, teachers are demanded to create lesson plan which will be implemented in learning process. Lesson plan becomes the teacher guidance to implement the learning process so that it is more directed and focuses on the objectives that are going to reach. Besides that, in Permendikbud No 103 of 2014, teachers are demanded to create le interactive, inspiring, challenging, enjoying and motivating learning process in order to make the students participate actively and give space for creativity and independency based on the talent and interest, physical development and psychology of the students.

Based on the interview with the Principal of SD N 4 Kaliuntu, it could be understood that there are some problems faced by the teachers in implementing Curriculum 2013, such as need long time to adapt with this curriculum, especially grade 3 and grade 6 homeroom teachers, because Curriculum 2013 does not consist of school subjects yet based on the theme. The grade 3 and 6 homeroom teachers are also not able to manage the class well. Some teachers are also confuse to make good lesson plan like what has been demanded by Permendikbud No 103 of 2014 because various subjects should be integrated into one theme and there are many aspects that should be assessed. The obstacle also happens when choosing the teaching media that is suitable with the theme. In order to know the effectiveness of the implementation of Curriculum 2013 based on Permendikbud No 103 of 2014, a research of the implementation of Curriculum 2013 which is focused on creating the lesson plan and observing the learning process was conducted in SD N 4 Kaliuntu. The research was a program evaluation. Arikunto (2008: 18) defines program evaluation as the effort to measure the level of the implementation of a policy accurately through the effectiveness of each components. This program evaluation aimed at identifying the accomplishment of the program objective by observing the implementation of the program. In order to know the discrepancy of the implementation of Curriculum 2013 in SD N 4 Kaliuntu based on Permendikbud No 103 of 2014, a research entitled "An Analysis of Discrepancy between the Lesson Plan and the Implementation of Curriculum 2013 in Teaching and Learning Process Based on Permendikbud No 103 of 2014 at SD Negeri 4 Kaliuntu, Buleleng Subdistrict, Buleleng Regency in the academic year 2016/2016" was conducted. The aims of this research were (1) analyzing the discrepancy between the lesson plan which was made by the teachers of SD N 4 Kaliuntu in the academic year 2015/2016 and the standard process which was stated in Permendikbud No 103 of 2014, (2) analyzing the discrepancy between the learning process of Curriculum 2013 which was implemented in SD N 4 Kaliuntu and the standard process which was stated in Permendikbud No 103 of 2014. 


\section{Method}

This study was an evaluative research which was conducted in SD N 4 Kaliuntu. Hadi and Mutrofin (2005:1) said, "Evaluative research aims at measuring the result of the policy, program, project, product or certain activity." Methodologically, this study was included as evaluative research because it was oriented on the analysis which based on program evaluation approach that analyzed the program discrepancy using variables of the standard and model of the discrepancy which were confirmed as the target of a program. The numbers of subjects were 6 . They were the homeroom teacher of grade $1,2,3,4$, 5, and 6 of SD N 4 Kaliuntu. Besides the teacher of SD N 4 Kaliuntu, another rsubject of this research was Permendikbud No 103 of 2014. The object of the research was teachers' lesson plan and the learning process which was conducted in SD N 4 Kaliuntu. This research was designed by using discrepancy model which was developed by Malcon Provus. The discrepancy model was the evaluative model which concerns on the perspective toward the discrepancy in the implementation of the program (Arikunto, 2008:48). This model was applied by the evaluator to measure the discrepancy level of every component of the program. The data which were collected through this research were lesson plan and learning process. The method of collecting the lesson plan data was documentation method by using the documentation instrument. The method that was used to collect the learning process data was observation method by using observation instrument.

The instrument of data collection was composed based on the materials that had been compiled according to Permendikbud 103 of 2014. Before it was implemented, the items of the instrument should be validated through content validity test. The content validity is the appropriateness between instrument and the target (Aimeay, 2012). This test was conducted to identify if the instrument had reflected the aspects which were going to be measured. The instrument validation process was conducted by two expert judges. The content validity measurement used Gregory formula. Based on the result of the judgment, it could be concluded that all instruments were valid and it could be used to collect the research data. Then, the data was analyzed. This study used non parametric test by following the procedure of level test that had Wilcoxon sign. Suciptawati (2009) stated that Wilcoxon test was non parametric test to examine the significance of comparative hypothesis of 2 couple sample. The Wilcoxon test aims at knowing if there was discrepancy between the standard of Permendikbud No 103 of 2014 and the real implementation which was conducted by the teachers of SD N 4 Kaliuntu. The steps of analyzing the data by using Wilcoxon test were (1) tabulating the score of each variable; (2) counting the mean score of each variable (Y); (3) comparing the mean score (Y) with the standard (X); (4) counting the direction (different sign) and the standard (X) with the mean score (Y), (X-Y); (5) counting the percentage of discrepancy standard $(\mathrm{X})$ and the mean score $(\mathrm{Y}),(\mathrm{X}-\mathrm{Y}) \%$; (6) confirming the different sign (+ ; -) and the discrepancy standard into categories (X); (7) if the different sign showed positive sign (+), it means that there was no discrepancy between standard and implementation; (8) if the different sign showed negative sign (-), it means that there was discrepancy between standard and implementation; (9) counting the percentage of negative discrepancy (-); (10) categorizing the level of discrepancy using the criteria that had been agreed. The criteria of discrepancy were explained as follows.

The result of the component analysis was intrepreted so that the data of lesson plan and learning process in SD N 4 Kaliuntu as the implementation of Curriculum 2013 which based on Permendikbud No 103 of 2014 were acquired. Then, the search, confirmation and conclusion toward the learning process in SD N 4 Kaliuntu which based on Permendikbud No 103 of 2014 had been observed by looking at the lesson plan and its implementation in the classroom. The instrument of data collection was composed according to the material which had been stated in Permendikbud No 103 of 2014. Before it was implemented, the items of the instrument should be validated through content validity test. The content validity is the appropriateness between instrument and the target (Aimeay, 2012). This test was conducted to identify if the instrument had reflected the aspects which were going to be measured. The instrument validation process was conducted by two expert judges. The content validity measurement used Gregory formula. Based on the result of the judgment, it could be concluded that all instruments were valid and it could be used to collect the research data. Then, the data was analyzed. This study used non parametric test by following the procedure of level test that had Wilcoxon sign. Suciptawati (2009) stated that Wilcoxon test was non parametric test to examine the significance of comparative hypothesis of 2 couple sample.

The Wilcoxon test aims at knowing if there was discrepancy between the standard of Permendikbud No 103 of 2014 and the real implementation which was conducted by the teachers of SD N 4 Kaliuntu. The steps of analyzing the data by using Wilcoxon test were (1) tabulating the score of each variable; (2) counting the mean score of each variable (Y); (3) comparing the mean score (Y) with the standard (X); (4) counting the direction (different sign) and the standard (X) with the mean score (Y), (X- 
$\mathrm{Y}$ ); (5) counting the percentage of discrepancy standard (X) and the mean score (Y), (X-Y)\%; (6) confirming the different sign (+ ; -) and the discrepancy standard into categories (X); (7) if the different sign showed positive sign $(+)$, it means that there was no discrepancy between standard and implementation; (8) if the different sign showed negative sign $(-)$, it means that there was discrepancy between standard and implementation; (9) counting the percentage of negative discrepancy (-); (10) categorizing the level of discrepancy using the criteria that had been agreed. The criteria of discrepancy were explained as follows. The result of the component analysis was intrepreted so that the data of lesson plan and learning process in SD N 4 Kaliuntu as the implementation of Curriculum 2013 which based on Permendikbud No 103 of 2014 were acquired. Then, the search, confirmation and conclusion toward the learning process in SD N 4 Kaliuntu which based on Permendikbud No 103 of 2014 had been observed by looking at the lesson plan and its implementation in the classroom.

Table 1. Lesson Plan

\begin{tabular}{cc}
\hline $\begin{array}{c}\text { Different quantities } \\
\text { (Standard) } \%\end{array}$ & Category of Discrepancy \\
\hline $\mathrm{D}=0$ & Without Discrepancy \\
$0<\mathrm{D} \leq 20$ & Very Small \\
$20<\mathrm{D} \leq 40$ & Small \\
$40<\mathrm{D} \leq 60$ & Moderate \\
$60<\mathrm{D} \leq 80$ & Big \\
$80<\mathrm{D} \leq 100$ & Very Big \\
\hline
\end{tabular}

\section{Findings and Discussion}

The component, subcomponent and indicator of the data collected data was firstly analyzed based on Permendikbud No 103 of 2014. It was conducted in order to identify the discrepancy of Curriculum 2013 implementation in SD N 4 Kaliuntu. The result of each indicator of lesson plan could be seen in table 2. Based on that table, it was found that there were six indicators which did not have discrepancy and 14 indicators had discrepancy between the standard and the learning preparation which was made by the teachers. The indicators that did not have discrepancy were indicator 1 (mentioning the unit of education), indicator 2 (mentioning the theme and subtheme), indicator 3 (mentioning the class and semester), indicator 5 (mentioning the core competency completely from KI-1 to KI-4), indicator 6 (mentioning the basic competency), and indicator 12 (the learning scenario consists of pre-activities, whilst activities and post activities). The indicators of lesson plan that have the very small discrepancy were indicator 4 (time allotment is suitable with the needs to achieve the basic compentency and the burden of learning) which had $6.6 \%$ of discrepancy, indicator 7 (basic competency should cover the spiritual character (basic competency of core competency 1), sosial character (basic competency of core competency 2), knowledge (basic competency of core competency 3), and skill (basic competency of core competency 4)) which had 3.4\% of discrepancy, indicator 8 (mentioning the indicators and summarized it based on basic competency) which had $10 \%$ of discrepancy, indicator 9 (teaching material should consists of facts, concept, principal and relevant procedure) which had 3.4\% of discrepancy, indicator 10 (learning material is written into classifications based on the summary of the indicator) which had $20 \%$ of discrepancy, indicator 11 (teaching scenario should be based on scientific approach and implement innovative teaching model) which had 3.4\% of discrepancy, indicator 13 (facilitate the students to learn independently) which had $13.4 \%$ of discrepancy, indicator 14 (teaching scenario which had been arranged makes the surrounding to be learning sources) which had 20\% of discrepancy, indicator 16 (the time allotment should be mentoned in every learning activities) which had $10 \%$ of discrepancy, indicator 17 (mentioning the assessment technique, instrument and remedial and enrichment) which had $16.6 \%$ of discrepancy.

Then, the components which had discrepancy with small category was indicator 15 which means that the indicator consisted of feedback and reinforcement plan. In this indicator, there was $23.4 \%$ of discrepancy. Another indicator which had small category was indicator 17 that mentioned the assessment technique, instrumented remedial and enrichment. It had $26.6 \%$ of discrepancy. The small category of discrepancy was also found in indicator 19. This indicator talked about using information and communication technology integratedly, systematically and effectively based on the situation and condition. It had $40 \%$ of discrepancy. The last indicator which had small discrepancy was indicator 20. This indicator mentioned the learning source such as books, mass media, electronic media, nature, and another relevant learning sources. It had $30 \%$ of discrepancy. 
Table 2. An Analysis of Discrepancy of Lesson Plan Indicator which was composed by the Teachers of SD Negeri 4 Kaliuntu

\begin{tabular}{|c|c|c|c|c|c|c|}
\hline \multicolumn{7}{|c|}{ Lesson planning } \\
\hline No Item & Standard & Score & $\begin{array}{l}\text { Different } \\
\text { sign }\end{array}$ & $\begin{array}{c}\text { Different } \\
\text { Values }\end{array}$ & $\begin{array}{l}\text { Percentage } \\
\text { Difference }\end{array}$ & Category \\
\hline 1 & 100 & 100 & - & 0 & 0 & WD \\
\hline 2 & 100 & 100 & - & 0 & 0 & WD \\
\hline 3 & 100 & 100 & - & 0 & 0 & WD \\
\hline 4 & 100 & 93.4 & - & -6.6 & 6.6 & VS \\
\hline 5 & 100 & 100 & - & 0 & 0 & WD \\
\hline 6 & 100 & 100 & - & 0 & 0 & WD \\
\hline 7 & 100 & 96.6 & - & -3.4 & 3.4 & VS \\
\hline 8 & 100 & 90 & - & -10 & 10 & VS \\
\hline 9 & 100 & 80 & -- & -20 & 20 & VS \\
\hline 10 & 100 & 80 & - & -20 & 20 & VS \\
\hline 11 & 100 & 96.6 & - & -3.4 & 3.4 & VS \\
\hline 12 & 100 & 100 & - & 0 & 0 & WD \\
\hline 13 & 100 & 86.6 & - & -13.4 & 13.4 & VS \\
\hline 14 & 100 & 80 & - & -20 & 20 & VS \\
\hline 15 & 100 & 76.6 & - & -23.4 & 23.4 & S \\
\hline 16 & 100 & 90 & - & -10 & 10 & VS \\
\hline 17 & 100 & 73.4 & - & -26.6 & 26.6 & $\mathrm{~S}$ \\
\hline 18 & 100 & 83.4 & - & -16.6 & 16.6 & VS \\
\hline 19 & 100 & 60 & - & -40 & 40 & $\mathrm{~S}$ \\
\hline 20 & 100 & 70 & - & -30 & 30 & $S$ \\
\hline Sum & 2000 & 1756.6 & - & -243.4 & 243.4 & \\
\hline Average & 100 & 87.83 & - & -12.17 & 12.17 & VS \\
\hline
\end{tabular}

From the data presentation in Table 2, the component of the lesson plan which had the biggest discrepancy was indicator 19 which was about the implementation of technology of information and communication integratedly, systematically and effectively based on the situation and condition. It had $40 \%$ of discrepancy. The mean score of the discrepancy of lesson plan indicator was $12.17 \%$. This discrepancy was belonged to very small category. The indicators which did not have discrepancy showed that the real condition was suitable with the standard (ideal condition). Whereas, the indicators which had discrepancy showed that there was differences between the real condition and the standard (ideal condition). The discrepancy was not only identified from the learning preparation, but also from the learning process. The result of the discrepancy of each learning process indicator was presented in Table 3. Based on the analysis, it was found that indicator 1 (create the good atmosphere to make the students ready to learn) did not have discrepancy between standard and the teaching and learning process that was condductd by the teacher. There were 11 indicators of learning process that had the discrepancy which were belonged to very small category.

That discrepancy were in indicator 3 (mentioning the competencies that were going to achieved and its benefits in daily life) which had $13.4 \%$ of discrepancy, indicator 4 (giving brief explanation about material and the activities which are going to be conducted) which had 10\% of discrepancy, indocator 6 (the whilst activities are conducted interactively, inspiringly, enjoyingly, challengingly, motivatedly in order to make the children participate actively) which had $6.6 \%$ of discrepancy, indicator 7 (the whilst activity of the learning process can give enough space for creator, creativity, and independency based on the talent, interest, physical development and psychology of the students (whuch had 20\% of discrepancy, indicator 8 (the students are facilitated to observe, question, collect information/try, associate, and communicate) which had $6.6 \%$ of discrepancy, indicator 9 (the teachers pay attention on the students' characters which are based on the basic competency from core competency 1 and 2 (such as be grateful to the God's blessing, honest, detailed, cooperative, tolerant, discipline, obey the rules, appreciate other's opinion) which had $16.6 \%$ of discrepancy, indicator 10 (teachers assess based on the basic competency from core competency 4) which had 205 of discrepancy, indicator 11 (the students are led to make summary or review of the lesson) which had $20 \%$ of discrepancy, indicator 13 (the students are given feedback toward the process and the learning achievement) which had 20\% of discrepancy, indicator 14 (the teachers assess the students learning achievement) which had 20\% of discrepancy, and indicator 16 (the teachers tell the next lesson plan) which had 6.6\% of discrepancy. 
Table 3. An Analysis of Discrepancy of Learning Process Indicator which was composed by the Teachers of SD Negeri 4 Kaliuntu

\begin{tabular}{|c|c|c|c|c|c|c|}
\hline \multicolumn{7}{|c|}{ Learning Implementation } \\
\hline No Item & Standard & Score & $\begin{array}{l}\text { Different } \\
\text { sign }\end{array}$ & $\begin{array}{c}\text { Different } \\
\text { Values }\end{array}$ & $\begin{array}{l}\text { Percentage } \\
\text { Difference }\end{array}$ & Category \\
\hline 1 & 100 & 100 & - & 0 & 0 & WD \\
\hline 2 & 100 & 66.67 & - & -33.4 & 33.4 & $\mathrm{~S}$ \\
\hline 3 & 100 & 86.87 & - & -13.4 & 13.4 & VS \\
\hline 4 & 100 & 90 & - & -10 & 10 & VS \\
\hline 5 & 100 & 46.67 & - & -53.4 & 53.4 & M \\
\hline 6 & 100 & 93.4 & - & -6.6 & 6.6 & VS \\
\hline 7 & 100 & 80 & - & -20 & 20 & VS \\
\hline 8 & 100 & 93.4 & - & -6.6 & 6.6 & VS \\
\hline 9 & 100 & 83.4 & -- & -16.6 & 16.6 & VS \\
\hline 10 & 100 & 80 & - & -20 & 20 & VS \\
\hline 11 & 100 & 80 & - & -20 & 20 & VS \\
\hline 12 & 100 & 63.4 & - & -36.6 & 36.6 & $\mathrm{~S}$ \\
\hline 13 & 100 & 80 & - & -20 & 20 & VS \\
\hline 14 & 100 & 80 & - & -20 & 20 & VS \\
\hline 15 & 100 & 76.67 & - & -23.4 & 23.4 & $\mathrm{~S}$ \\
\hline 16 & 100 & 93.4 & - & -6.6 & 6.6 & VS \\
\hline Sum & 1600 & 1293.88 & - & -306.12 & 306.12 & \\
\hline Average & 100 & 80.8675 & - & -19.1325 & 19.1325 & VS \\
\hline
\end{tabular}

Table 3 showed that the component of learning process that had discrepancy and belonged to small category was in indicator 2 which was about giving apperception related to the competency that had been learnt and the competency that would be learnt. In this indicator, the discrepancy was $33.4 \%$. Another component that had discrepancy was indicator 12. It was about leading the students to reflect what had been learnt. Its discrepancy was 36.6\%. The last indicator which belonged to small category of discrepancy was indicator 15. It was about teachers' plan of giving follow up activities such as remedial tes, enrichment, counseling and/or individual and group assignment which based on their learning achievement. Its discrepancy was $23.4 \%$.

Then, based on Table 3, it was found that the components of lesson plan that had highest discrepancy was indicator 5 that was about the scope and technique of assessment. The discrepancy of this indicator was 53.4\%. The result of the analysis showed that the components of learning implementation or learning process in indicator 5 had average category. According to the documentation study and data analysis, it could be understood that the mean score of the lesson plan which was made by the teachers of SD N 4 Kaliuntu was 87.83. It meant that there was $12.17 \%$ of discrepancy and belonged to very small category. Therefore, by paying attention on the result of data analysis, several components or indicators of the lesson plan which was composed by the teachers was not suitable with Permendikbud No 103 of 2014. Those discrepancy was in the subcomponent of time allotment. The time allotment which was stated in the lesson plan which was composed by the homeroom teacher of grade 3 and grade 6 was not suitable because they mentioned different amount of time in the time allotment which was in the identity of the lesson plan and the time allotment which was in the component of teaching scenario.

The discrepancy was also found in the subcomponent of basic competency. In permendikbud No 103 of 2014, the basic competency should cover the spiritual character (basic competency of core competency 1), sosial character (basic competency of core competency 2), knowledge (basic competency of core competency 3), and skill (basic competency of core competency 4). However, the real implementation which was found in SD N 4 Kaliuntu only consisted of basic competency of core competency 3 and core competency 4. The discrepancy was also found in the subcomponent of the indicator that was about the competency accomplishment. It was conveyed based on the basic competency. The homeroom teacher of grade 1, grade 3 and grade 4 only stated the indicator of the basic competency of core competency 3 and basic competency of the core competency 4 . There was also the discrepancy in the subcomponent of the teaching material in the lesson plan. Permendikbud No 103 of 2014 stated that the lesson plan of Curriculum 2013 should consist of the fact, concept, principal, and relevant procedure. The material which was made by the teachers of SD N 4 Kaliuntu was not complete. Next, the discrepancy was also found in the subcomponent of the teaching scenario. In the lesson plan 
which was made by the grade 3 teacher of SD N 4 Kaliuntu, the teaching and learning model which was implemented was not innovative. Another discrepancy could be found in the indicator that facilitated the students to learn individually because the learning process was more focused on the group discussion. The individual learning was led to answering the questions which were written in the students' book.

The discrepancy of the subcomponent of the learning process was found in the indicator that made the surroundings (class and school yard) become the learning sources. Several lesson plans did not use the surroundings to be the learning sources. The lesson plans which were made by the teachers only used several particular objects. The discrepancy was also identified in the indicator that was about giving positive feedback and reinforcement. The lesson plan which was made by the teachers, especially the grade 4 teacher, did not arrange the feedback which was based on what had been stated in Permendikbud No 103 of 2014. The next discrepancy happened in the subcomponent of learning achievement. It was found in the lesson plans which were made by the teacher of grade 3 , grade 4 , and grade 6 . In the subcomponent of learning achievement, the teacher of grade 3, grade 4 and grade 6 only mentioned the technique and the instrument of the assessment. The discrepancy was also found in the lesson plans which were made by the teacheers of SD N 4 Kaliuntu, especially the subcomponent of media and learning sources. It was located in the indicator of the application of information and communication technology. The lesson plans which were created by the teachers of all grades that became the object of this research did not apply the information and communication technology. Besides, the discrepancy was also found in the indicator of the learning sources. The sources included books, mass media, electronic media nature and the other relevant learning sources. The learning sources which were stated in the lesson plans made by the teachers of grade 2, grade 3 and grade 6 were not variative. The learning sources were only books from the government.

The result of the evaluation program was a recommendation to make a decision (Arikunto, 2008). The discrepancy of the object of lesson plan made by the teachers of SD N 4 Kaliuntu was $12.17 \%$ and categorized as very small. Because of that, the learning process which was conducted by the teachers was appropriate to be implemented in SD N 4 Kaliuntu by fixing some components that was not suitable with the standard (Permendikbud No 103 of 2014). Then, the observation result of the learning process which was conducted in SD N 4 Kaliuntu was analyzed. Its result showed that there was 19.17\% of discrepancy which belonged to very small category. Based on the result of the data analysis, there were several components or indocators of the learning process which were not suitable with Permendikbud No 103 of 2014. First discrepancy was found in the pre-activities, especially the apperception. Most of all the teachers in SD N 4 Kaliuntu did not explain the apperception that related the competency that had been learnt and the competency that would be learnt. Then, the discrepancy of subcomponent of the preactivity was also found in the indicator that was about competency that should be achieved and its benefits in the daily life. Based on the observation result, it was found that the tea homeroom teachers of grade 1 , grade 2 , grade 3 and grade 4 did not tell the students about the competency which was going to be achieved and its benefit for daily life clearly. The discrepancy was also found in the indicator of the lesson plans which were made by the teachers of grade 1, grade 2 and grade 4 . In this indicator, the teachers did not explain the teaching material completely.

The highest discrepancy of the subcomponent of the pre-activities was in the indicator that was about the scope and technique of the assessment which were going to be conducted. Almost all the teachers did not tell the students about the technique of the assessment. It was not suitable with Permendikbud No 103 of 2014 that demanded the teachers to explain the assessment technique which would be applied in the pre-activities. According to the observation which had been conducted, there were some discrepancies which were found in this subcomponent. Those discrepancies were identified in several indicators. The first discrepancy was found in the indicator which was about the interactive, inspiring, enjoying, challenging, and motivating activities to make the students participate actively. Based on the result of the observation, the grade 3 and grade 6 teacher could not make the students to be active during the learning process because there were only few students who performed actively in the classroom. The discrepancy was also found in the subcomponent of whilst activity. Teachers did not give enough space for the idea, creativity and independency of the students' talent, interest, physical development and psychology. For this indicator, what had been implemented by the teacher needed to be fixed because they had not implemented it based on Permendikbud No 103 of 2014.

Then, there was a discrepancy in the indicator of performance assessment which was about assessing basic competency of core competency 4. Almost all of the teachers had conducted the performance assessment for the students but it still needed to be improved. By looking at the data analysis, the whilst activity of learning process which was conducted by the teachers of SD N 4 Kaliuntu was almost suitable with Permendikbud No 103 of 2014. There were only few indicators which had discrepancy. Next, there was also discrepancy in the subcomponent of post activities. The first indicator 
which had discrepancy was the indicator that was about the way to lead the students to make summary or review of the lesson. Actually, teachers had conducted this activity but because of the limited of time, some teachers did not ask the students to review the lesson completely. It happened in grade 1, grade 2 and grade 3. Then, the discrepancy was also found in the indicator which was about the teachers' way to lead the students to reflect the activities that had been conducted.

The discrepancy in the subcomponent of the post activities could also be found in the indicator which was about the activities of giving feedback to the students related to their learning process and achievement. For this indocator, the discrepancy was done by all teachers. It was because the feedback given by the teachers was not suitable with the students' learning process and achievement. It meant that the activities conducted by the teachers in giving feedback were not suitable with what had been stated in Permendikbud No 103 of 2014. Besides, the discrepancy was also found in the subcomponent which was about giving follow up activities in the form of remedial test, enrichment, and assignment. Giving follow up activities like remedial, enrichment and assignment aimed at improving the students' understanding and fixing the students' learning achievement so that it would reach the standard. However, this discrepancy was experienced by all teachers because none of them conducted it completely. The discrepancy was also identified in the indicator which was about telling the material for the next meeting. It happened in grade 3 and grade 4 because the teachers only told the students the page of the book which was going to be learnt for the next meeting. They did not tell them the material directly.

Madaus (in Putro, 2011) stated that discrepancy model was evaluation model which was begun from assumption in order to identify the appropriateness of a program, evaluator can compare between what should be happened and what is expected to happen (standard) with what is actually happen (performance) so that the discrepancy among both standard and performance can be identified. The result of the evaluation program was a recommendation from the evaluator to decise a decision (Arikunto, 2008). The discrepancy of the learning process which was conducted by the teachers of SD N 4 kaliuntu was about $19.17 \%$. It was belonged to very small category. Therefore, the learning process which was conducted by the teachers was appropriate to be implemented by fixing some components that was not suitable with the standard (Permendikbud No 103 of 2014).

\section{Conclusions}

Based on the data analysis, it can be concluded that (1) the discrepancy level between the implementation of Curriculum 2013 in SD Negeri 4 Kaliuntu and Permendikbud No. 103 of 2014 which was considered from the lesson plan identification was $12.17 \%$ and it fell into very small category. The discrepancy was found in the indicators, teaching scenario, assessment, media and learning sources. (2) The discrepancy level between the implementation of Curriculum 2013 in SD Negeri 4 Kaliuntu and Permendikbud No. 103 of 2014 which was considered from the learning process identification was $19.17 \%$ and it fell into very small category. The discrepancy was found in the implementation of apperception, assessment, students' reflection towards the lesson, and reinforcement in the form of remedial test, enrichment and homework.

In order to solve the discrepancy of Curriculum 2013 implementation and improve the appropriate implementation which based on Permendikbud No. 103 of 2014 in teaching and learning process, several related parties must work together and decide the regulations and arrange a program that that could improve the tachers' understanding toward teaching and learning process which is suitable with Permendikbud No. 103 of 2014. There are several suggestions related to the discrepancy. (1) Teacher should be adaptive toward the changes of the curriculum and regulation and also improve their skill in implementing Curriculum 2013 by following the workshop such as KKG and etc. (2) The headmaster should evaluate the teachers' work in making the lesson plan and observe the teacher's way in implementing the curriculum in learning process so that if there was something inappropriate with the standard, it could be corrected. The headmaster also should instruct the teachers to join the workshop on composing lesson plan and implementing Curriculum 2013 which based on Permendikbud No. 103 of 2014. (3) the government should hold an intensive socialization related to the teaching and learning process which based on the standard to the teachers through workshop, training, seminar and other activities which are more focused on the steps of creating the lesson plan and conducting the learning process starting from pre-activities, whilst activities and post activities which are based on Permendikbud No 103 of 2014. (4) The researcher should conduct the research on the evaluation of Curriculum 2013 implementation in a wider unit of education to identify if there are some discrepancies in the implementation of Curriculum 2013 so that it could be solved. It is also expected that this curriculum can improve the quality of education to develop our country. 


\section{References}

Arikunto, Suharsini dan Cepi Safrudin Abdul Jabar. 2008. Evaluation of Education Program. Jakarta: Bumi Aksara

Arikunto, S. 2006. Research Procedures A Practice Approach. Jakarta: Reneka Cipta.

Hadi, Samsul dan Mutrofin. 2005. Introduction to Evaluation Research methods.Yogyakarta: PT. Kurnia Kalam Semesta.

Kamil, Ahmad. 2014. The Importance of the Curriculum in Education. Available on http://www. kompasiana.com/achmadkamil/pentingnya-kurikulum-terhadap prosespendidikan (15 Desember 2015)

Kemendikbud Kementrian Guru dan Kebudayaan 2012. Curriculum 2013. Jakarta: Kementerian Guru dan Kebudayaan.

Kemendikbud Kementrian Guru dan Kebudayaan 2013. Pedoman Pelatihan Implementasi Kurikulum 2013. Jakarta: Kementerian Guru dan Kebudayaan.

Kemendikbud Kementrian Guru dan Kebudayaan 2014. Process Assessment Model and Learning Outcomes. Jakarta: Kementerian Guru dan Kebudayaan.

. 2013b. Teacher Training Material Implementation of Curriculum 2013 SMP / MTs Natural Sciences. Jakarta: Kementerian Guru dan Kebudayaan.

Kurniasih, Imas dan Berlin Sani. 2014. Successful Implementing Curriculum 2013. Jakarta: Kata Pena

Pantiwati. 2013. The essence of authentic assessment and its application in biological learning. JEMS (Jurnal Edukasi Matematika dan Sains) 1 (1):1-10.

Permendikbud Peraturan Menteri Guru dan Kebudayaan 2014. Minister of Teachers and Culture of the Republic of Indonesia Regulation No. 104 of 2014 on Assessment of Learning Outcomes by Educators on Basic Education and Secondary Education. Jakarta: Kementeri Guru dan Kebudayaan.

Pertiwi, Putu Arik Indah. 2015. "Analisis diskrepansi pembelajaran kurikulum 2013 berdasarkan permendikbud nomor 65 tahun 2013 di SD Negeri 3 Banjar jawa”. Undiksha. Volume 3, Nomor 1. Available on http://ejournal.undiksha.ac.id/index.php/JJPGSD/article/viewFile/5154/3896 (10 Nopember 2015).

Putro, Eko Widoyoko. 2011. Evaluation of Learning Program. Yogyakarta: Pustaka Pelajar

Suciptawati, Ni Luh Putu. 2009. Nonparametric Statistics Method. Denpasar: Udayana University Press

Sudarma, I Made. 2011. Analysis of the Implementation of Standard Implementation of Science and Technology Subject Group Process at International Standard School in Klungkung Regency Year 2010/2011. Tesis (not published) Post Graduate Program, Universitas Pendidikan Ganesha 